\title{
Characteristic, Thermochemical Behaviors and Kinetic of Demineralized and Torrefied Empty Fruit Bunches (EFB)
}

Nur Nasulhah Kasim ${ }^{*}, 1,2$, Khudzir Ismail ${ }^{1,2}$, Alina Rahayu Mohamed ${ }^{3}$, Mohd Azlan Mohd Ishak ${ }^{1,2}$, Razi Ahmad ${ }^{2,4}$, Wan Izhan Nawawi Wan Ismail ${ }^{1,2,5}$

${ }^{1}$ Coal and Biomass Energy Research Group, Universiti Teknologi MARA (UiTM), 40450, Shah Alam, Selangor, Malaysia

${ }^{2}$ Faculty of Applied Sciences, Universiti Teknologi MARA Malaysia, 40450 Shah Alam, Selangor, Malaysia

${ }^{3}$ Faculty of Engineering Technology, Unicity Alam, UniMAP, Padang Besar, 02400 Perlis, Malaysia

${ }^{4}$ School of Environmental Engineering, Universiti Malaysia Perlis, 02600 Arau, Perlis, Malaysia

${ }^{5}$ Department of chemistry, University York, Heslington, YO10 5DD, United Kingdom

\section{A R T I C L E I N F O}

Article history:
Received: 13 August, 2018
Accepted: 30 September, 2018
Online: 18 October, 2018

Keywords:

Demineralization

Torrefaction

Empty fruit bunches (EFB)

$T G A$

Coats-Redfern method

\begin{abstract}
A B S T R A C T
A sequential pre-treatment of demineralization and torrefaction, was carried out on palm empty fruit bunches (EFB). EFB and demineralized EFB (DEFB) were torrefied in a vertical tubular reactor in the temperature range of 200 to $280{ }^{\circ} \mathrm{C}$ for $30 \mathrm{mins}$ under nitrogen (flow rate:100 $\mathrm{mL} / \mathrm{min}$. The pretreated samples were characterized using proximate and ultimate analyses, fuel properties, and Fourier-transform infrared (FTIR) spectroscopy techniques. The thermal and kinetic study on the torrefied samples were carried out using thermogravimetric analysis. The results showed that sequential pretreatment enhances the properties of solid EFB by increasing the carbon content and reducing the oxygen content with increasing the calorific value. Fuel properties of torrefied samples showed the mass and energy yield decreased, with an increase in energy density. In addition, the FTIR spectra showed the decomposition of hemicellulose occurring for torrefied samples as evidenced by the disappearance of the vibrational features belonging to hydroxyl and carbonyl groups. The kinetic study carried out using Coats-Redfern method on torrefied samples suggested that the activation energy can be transferred by the sequential pre-treatment, indicating that the abundant energy it has can be converted into bio oil of high quality. Apparently, torrefied samples bear high potential to be used as biofuel feedstock when exposed to further thermal decomposition and pyrolysis processes.
\end{abstract}

\section{Introduction}

This paper is an extension of work the originally presented in 4th IET Clean Energy and Technology Conference (CEAT 2016) [1]. The extended work was focused on sequential pre-treatment of demineralization and torrefaction of empty fruit bunches (EFB) feedstock. Characteristic and fuel properties of pre-treated EFB were investigated and its kinetic study was performed using CoatsRedfern method.

Depletion of energy resources is a crucial issue which has been challenged worldwide. Fossil fuel energy resources such as

*Corresponding Author: Nur Nasulhah Kasim, Universiti Teknologi MARA

Malaysia, +604-9882000, nurnasulhah@perlis.uitm.edu.my

Www.astesj.com

https://dx.doi.org/10.25046/aj030542 petroleum, natural gas and coal are expected to last for approximately 35 years, 37 years and 104 years, respectively [2]. Utilization of agricultural waste seems to assist the shortage of energy resources especially for countries having such resources [3]. Malaysia is the second largest producer of palm oil giving rise to abundant oil palm wastes during the refined, bleached and deodorized (RBD) palm oil processing[4].

Previously, many researchers have focussed on the utilisation of the oil palm waste such as empty fruit bunches (EFB) [5], oil palm fronds (OPF) [6], mesocarp fibre (MF) and palm kernel shell (PKS) $[6,7,8]$ due to their potential benefits for energy sources. However, hygroscopic behavior and higher content of alkali and alkaline earth metals (AAEMs) particularly in EFB limits the 
utilization of biomass in producing the energy due to vulnerable to biological attack and biodegradation [10]. In addition, nearly $60 \%$ of water contained in wet EFB and the heating value of the dry EFB is roughly half that of palm oil [4].Thus, EFB is unsuitable to be directly burnt for energy production. Therefore, some pretreatments need to be introduced on EFB prior to pyrolysis to produce high quality of bio oil that contain hydrocarbon content with low carboxylic acid molecules $[9,10]$.

From previous research, feasible pre-treatments on EFB have been investigated such as demineralization and torrefaction in order to enhance the properties of biomass prior to thermal conversion $[11,12,13]$. Demineralization is an efficient pretreatment that can be carried out using water, acid or alkaline solution to eliminate the inorganic compounds that assist the secondary reaction during the pyrolysis. Although water reduced about $50 \%$ concentration of inorganic compounds in most of the biomass, chemicals like acid and alkali solution eliminated almost $100 \%$ of the compounds $[14,15]$.

Generally, torrefaction is the often-applied pre-treatment to improve the quality of biomass. The process is carried out in an inert condition at atmospheric pressure between the temperatures of $200-320^{\circ} \mathrm{C}$. This process is a mild version of slow pyrolysis with the aim of reducing the carbonyl, carboxyl, hydroxyl group compounds, and lowering moisture and oxygen contents. In addition, the grindability and hydrophobicity are improved by breaking down the cell wall and fiber structures of the biomass [11]. Washing, drying and size reduction on biomass is a simple pre-treatment that need to be prepared prior to pyrolysis [18]. Basically, an efficient pre-treatment was seen to be easier, economic and less time consuming with simple processing steps. Nevertheless, single pre-treatment such as demineralization or torrefaction alone was as an inappropriate method to obtain high quality bio oil $[9,15,17]$ from raw EFB having high AAEMs and oxygen content.

Previously, application of demineralization and torrefaction sequentially was reported as a novel promising method to reduce the undesirable natural catalyst (AAEMs), moisture, acetyl and acid contents of the biomass samples [10,17]. Therefore, a combination of demineralisation and torrefaction processes was applied to reduce the oxygen, carboxyl, water and ash contents of biomass [19]. Similarly, demineralization using water washing technique combined with torrefaction pre-treatment on microwave pyrolysis of rice husk resulted in large elimination of inorganic compounds which thus, could enhance the quality of fuel characteristic [17].

Pyrolysis of biomass such as EFB, PKS, cotton stalk and rice straw has been performed under dynamic non-isothermal condition in thermogravimetric analyser. To our best knowledge, a few investigations on thermal behaviour and most kinetic studies of biomass pyrolysis have been done using thermogravimetric analyser $[4,18,19,20]$. In addition, more information or data on kinetic parameters, i.e., activation energy, pre-exponential factor, reaction order and mechanism of reaction can be generated from thermogravimetric analysis [23].

However, there is limited information about physicochemical properties of TEFB and TDEFB at various torrefaction temperatures and very scarce information is available on pyrolysis of demineralized torrefied biomass especially using model free method to calculate activation energy. Thus, the present study was performed to investigate the effect of the sequential application of demineralisation and torrefaction at $200,220,240,260$ and $280{ }^{\circ} \mathrm{C}$ to enhance the solid fuel qualities.

The basic characteristic of pretreated oil palm EFB including proximate and ultimate analyses, fuel properties and FTIR analysis were elucidated for further utilization of this biomass feedstock. Furthermore, the thermal behaviour and kinetic study of the selected torrefied EFB (i.e. TEFB 240) and torrefied demineralized EFB (i.e. TDEFB 240) were also searched during pyrolysis using thermogravimetric analysis. These data are of significant importance to understand the thermal decomposition and for further effective upgrading of the pre-treatment process. Besides, the thermochemical evolution profiles help designing suitable reactor and setting the optimum condition parameters for the system.

\section{Methodology}

\subsection{Biomass samples preparation}

The empty fruit bunches (EFB) were collected from the United Oil Palm Industries Sdn Bhd located in Nibong Tebal, Pulau Pinang, Malaysia. The biomass was rinsed with tap water to remove impurities and dried in oven at $105^{\circ} \mathrm{C}$ for $24 \mathrm{~h}$. It was ground using a hammer mill machine into small particle size and sieved using the sieve shaker to $0.5-1.0 \mathrm{~cm}$. Finally, the dried biomass was stored in air-tight containers for further use.

\subsection{Sample labels}

Untreated EFB, demineralized EFB, torrefied EFB, torrefied demineralized EFB, EFB torrefied at $240{ }^{\circ} \mathrm{C}$ and torrefied demineralized EFB at $240{ }^{\circ} \mathrm{C}$ were represented as EFB, DEFB, TEFB240 and TDEFB240, respectively.

\subsection{Demineralization of EFB (DEFB)}

Demineralization of EFB was carried out to eliminate AAEMs that reduce the ash content in the sample. From our preliminary work, sonication for $10 \mathrm{~min}$ of EFB in $1 \%$ nitric acid solution at room temperature gave positive results with minimum ash content of $0.74 \%$ in comparison to $4.21 \%$ in untreated EFB [1]. This demineralized EFB sample was used for torrefaction study here.

$100 \mathrm{~g}$ of EFB was placed in a flask containing $500 \mathrm{~mL}$ of $1 \%$ nitric acid and was sonicated for $10 \mathrm{~min}$ in ultrasonic bath at room temperature. After acid leaching, the sample was filtered and dried at $105{ }^{\circ} \mathrm{C}$ for $24 \mathrm{~h}$ to a constant weight. Weight measurements for all samples before and after the pre-treatment were carried out using an electronic balance.

\subsection{Torrefaction experiment}

Torrefaction experiments were performed in a vertical tube fixed bed reactor shown schematically in Figure 1. Each experiment was conducted with $2.0 \mathrm{~g}$ of untreated and demineralized EFB samples in inert atmosphere under nitrogen flow $(100 \mathrm{~mL} / \mathrm{min})$ from ambient temperature to various torrefaction temperatures of $200,220,240,260$ and $280{ }^{\circ} \mathrm{C}$, bu keeping at the selected temperature for $30 \mathrm{~min}$. Nitrogen flow was purged before and after 5 min of the experiment and the sample was removed from the reactor after cooling.

\subsection{Characterization of EFB, TEFB and TDEFB samples}

For each sample, the moisture and ash content, calorific value and ultimate and proximate analyses were carried out. The 
moisture content was measured by drying the samples at $105^{\circ} \mathrm{C}$ for $4 \mathrm{~h}$ [24]. The total ash content and calorific value were determined by ASTM E-1755-01 [25] and ASTM D 2015 - 96 [26] using LECO bomb calorimeter AC-350, respectively. The ultimate analysis of EFB samples was performed according to ASTM D3176 [27] using CHNS-O Flash 2000 with O content determined by difference. Proximate analysis of EFB, TEFB and TDEFB was carried out using Mettler Toledo thermogravimetric analyser (TGA). $10.0 \mathrm{mg}$ of samples were pyrolyzed from ambient temperature to $900{ }^{\circ} \mathrm{C}$ at the heating rate of $20^{\circ} \mathrm{C} / \mathrm{min}$. The volatile matter was determined using TG/DTG curves and fixed carbon was calculated by difference.

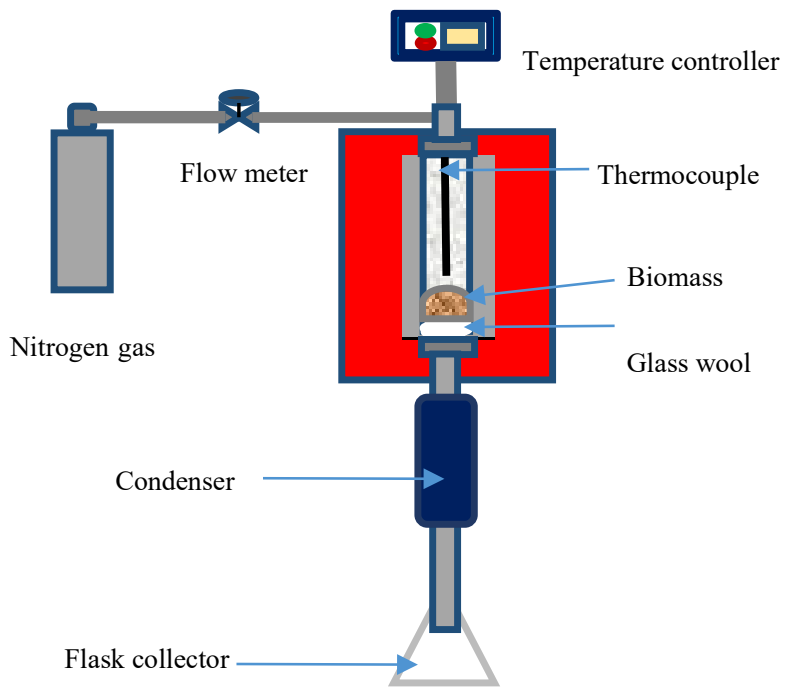

Figure 1. Schematic diagram of torrefaction reactor furnace

The Inductive couple plasma optical emission spectrometer (ICP-OES) was used to determine the inorganic metal content of the EFB and DEFB samples. $300 \pm 10 \mathrm{mg}$ of samples were digested with $2.5 \mathrm{~mL}$ of $65 \%$ nitric acid and $2.5 \mathrm{~mL}$ of $30 \%$ hydrogen peroxide $\left(\mathrm{H}_{2} \mathrm{O}_{2}\right)$ in high performance microwave digestion system, Ethos One. The temperature was ramped to 90 ${ }^{\circ} \mathrm{C}$ over $15 \mathrm{~min}$, held for $5 \mathrm{~min}$, then ramped again to $180{ }^{\circ} \mathrm{C}$ over $10 \mathrm{~min}$ and held for $15 \mathrm{~min}$ [11]. The digested samples were analysed using Perkin Elmer Optima 8000 ICP-OES.

Qualitative analysis of functional groups in each EFB samples was conducted using Perkin Elmer Fourier-transform infrared spectroscopy (FTIR) technique. The samples were scanned in the range from $4000-600 \mathrm{~cm}^{-1}$ at a resolution of $4 \mathrm{~cm}^{-1}$. For fuel properties analyses, the mass and energy yields of each samples were calculated using equations (1), (2) [28] and energy density equation (3) [29].

$$
\text { Mass yield }\left(Y_{\text {mass }}\right)=\frac{\text { Mass after torrefaction }}{\text { Mass of raw sample }} \times 100 \%
$$

$$
\begin{gathered}
\text { Energy yield }\left(Y_{\text {energy }}\right)=Y_{\text {mass }} \times \frac{\text { heating value of torrefied sample }}{\text { heating value of raw sample }} \times 100 \% \\
\text { Energy density }\left(Y_{\text {energy density }}\right)=\frac{\text { Energy yield }\left(Y_{\text {energy }}\right)}{\text { Mass yield }\left(Y_{\text {mass }}\right)}
\end{gathered}
$$

Thermal and kinetic analyses of the EFB, TEFB240 and TDEFB240 samples were carried out using a Mettler Toledo thermogravimetric analyser. $10.0 \mathrm{mg}$ of each EFB sample pyrolysed at the heating rate of $20^{\circ} \mathrm{C} / \mathrm{min}$ under nitrogen flow $(100$ $\mathrm{mL} / \mathrm{min}$ ) from ambient temperature to $900{ }^{\circ} \mathrm{C}$.

In this study, Coats-Redfern method which is widely used to follow the thermal decomposition of biomass [4,18,20,28] was applied for modelling the decomposition kinetics of raw EFB, TEFB240 and TDEFB240 samples. By this method, kinetic parameters such as activation energy, $E_{a}$ and pre-exponential factors, In A can be determined. In kinetic analysis, the rate of pyrolysis was assumed as:

$$
\frac{d \alpha}{d t}=k f(\alpha)
$$

In this equation, $\alpha$ represents the progress of reaction or the conversion which occurs between 0.05 to 0.95 . $\alpha$ is the progress of reaction during the biomass decomposition which can be defined as:

$$
\alpha=\frac{w_{0}-w_{t}}{w_{0}-w_{f}}
$$

where $\mathrm{w}_{0}, \mathrm{w}_{\mathrm{t}}$, and $\mathrm{w}_{\mathrm{f}}$ are the initial, current (at time $\mathrm{t}$ ) and final weight of the biomass samples. The rate is constant and dependent on the activation energy $\left(\mathrm{E}_{\mathrm{a}}\right)$.

$$
k=A \exp \left(-\frac{E_{a}}{R T}\right)
$$

Considering the assumption of the Coats-Redfern method $(2 \mathrm{RT} / \mathrm{E}<<1)$, and following the first order reaction kinetic, equation (7) represents the kinetic equation used to calculate the activation energy $\left(\mathrm{E}_{\mathrm{a}}\right)$ and pre-exponential factors, $\ln \mathrm{A}$.

$$
\ln \left[-\frac{\ln (1-\alpha)}{T^{2}}\right]=\ln \left[\frac{A R}{\beta E_{a}}\left[1-\frac{2 R T}{E_{a}}\right]\right]-\frac{E}{R T}
$$

According to kinetic equation (7), the plot of $\ln \left[-\ln (1-\alpha) / \mathrm{T}^{2}\right]$ against $1 / \mathrm{T}$ give a correlation straight line with the first order kinetics. The activation energy and the pre-exponential factor, In A can be determined from the slope and the intercept of the straight line, respectively [31].

\section{Result and Discussion}

\subsection{Proximate analysis of EFB, DEFB, TEFB and TDEFB}

The proximate analysis of EFB, DEFB, TEFB and TDEFB is shown in Table 1. Apparently, the ash content of DEFB dramatically decreased to 0.74 wt. \% in comparison with EFB at $4.21 \%$.

Moreover, the effect of torrefaction on DEFB (represented as TDEFB) can be seen from the increase in the ash content changing in the range from $1.31-2.69 \%$. Likewise, for TEFB, as the torrefaction temperature increased from 200 to $240{ }^{\circ} \mathrm{C}$, the ash content increased slightly and almost doubled at a higher torrefaction temperature of $260-280{ }^{\circ} \mathrm{C}$ in comparison with EFB. It was due to the induces partial removal of volatiles from biomass 
after the torrefaction pre-treatment. Indeed, torrefaction has a marked effect on the ash content of both the TEFB and TDEFB samples. This implies that sequential application of demineralization and torrefaction on EFB reduced the ash content and offset the negative impact on the increased of ash content due to torrefaction [19].

Table 1. Proximate analysis of EFB, TDEFB and TDEFB

\begin{tabular}{llll}
\hline Sample & \multicolumn{3}{l}{ Proximate analysis $(\% \mathrm{db})$} \\
\cline { 2 - 4 } & $\begin{array}{l}\text { Volatile } \\
\text { matter }(\mathrm{VM})\end{array}$ & $\begin{array}{l}\text { Fixed } \\
\text { carbon }(\mathrm{FC})\end{array}$ & \\
\hline EFB & 53.85 & 41.93 & 4.21 \\
\hline DEFB & 73.60 & 25.65 & 0.74 \\
\hline TEFB 200 & 72.95 & 22.49 & 4.54 \\
TEFB 220 & 72.54 & 22.64 & 4.81 \\
TEFB 240 & 45.95 & 49.12 & 4.91 \\
TEFB 260 & 46.83 & 44.67 & 8.49 \\
TEFB 280 & 46.81 & 43.59 & 9.58 \\
\hline TDEFB 200 & 59.23 & 39.45 & 1.31 \\
TDEFB 220 & 56.27 & 42.35 & 1.37 \\
TDEFB 240 & 63.04 & 35.08 & 1.87 \\
TDEFB 260 & 69.09 & 29.13 & 1.76 \\
TDEFB 280 & 47.98 & 49.32 & 2.69 \\
\hline
\end{tabular}

With reference to volatile matter content, TEFB at low torrefaction temperature range of 200 and $220{ }^{\circ} \mathrm{C}$ showed a drastic increase by about $35 \%$ in comparison to that of EFB. On contrary, fixed carbon at low torrefaction temperatures $\left(200-220{ }^{\circ} \mathrm{C}\right)$ of TEFB decreased by $46 \%$ which is significant. This trend can be explained by the dehydration and decarboxylation of hemicellulose which occurring at lower torrefaction temperature [30,31]. During the dehydration and decarboxylation, hemicellulose decomposes into $\mathrm{H}_{2} \mathrm{O}, \mathrm{CO}_{2}, \mathrm{CO}$ and solid char as well as low molecular weight hydrocarbon [28].

Consequently, at the higher torrefaction temperature range from 240 to $280^{\circ} \mathrm{C}$, volatile matter of TEFB was found to decrease with the increase in fixed carbon. This observation is attributed to the initial thermal decomposition of cellulose [34] which completely destroys the cell structure of EFB and causes a further increase in the amount of fixed carbon during high torrefaction temperature [26,33].

As for TDEFB, the volatile matter content became slightly higher with the reduction in fixed carbon content in the torrefaction temperature range from 200 to $260{ }^{\circ} \mathrm{C}$ in comparison with EFB. These results indicated a slow rate decomposition of hemicellulose in DEFB during torrefaction. Similar observation was also reported in other studies investigated the influence of inorganic metals on the decomposition of biomass [36]. In contrast, at the torrefaction temperature of $280{ }^{\circ} \mathrm{C}$ of TDEFB, the reduction of volatile matter and the increase in fixed carbon content were observed.

This observation might be due to the extensive decomposition of hemicellulose into volatiles and solid products that took place at more severe torrefaction condition [37]. These results indicated that demineralization pre-treatment influenced the degradation of lignocellulosic components in EFB and facilitated the decomposition of hemicellulose and cellulose at different temperatures during torrefaction pre-treatment.

\subsection{Ultimate analysis and calorific value of EFB, DEFB, TEFB and $T D E F B$}

The $\mathrm{H} / \mathrm{C}$ ratio, $\mathrm{O} / \mathrm{C}$ ratio and calorific value for $\mathrm{EFB}, \mathrm{DEFB}$, TEFB and TDEFB are listed in Table 2. The ultimate analysis revealed the alterations of chemical composition of EFB which occurred after the pre-treatment of demineralization and torrefaction. The carbon content was found to increase for single sequential pre-treatment of demineralization and torrefaction. When the torrefaction temperature was increased, the carbon content gradually increased whereas hydrogen and oxygen contents of TEFB and TDEFB samples decreased. These findings can be explained by the effects of dehydration, decarboxylation, and demethanation reactions of hemicellulose [38] and partial depolymerization of cellulose during torrefaction [34].

In the literature [35], the atomic ratio of $\mathrm{O} / \mathrm{C}$ and $\mathrm{H} / \mathrm{C}$ in biomass are found between 0.4 to 0.8 and 1.2 to 2.0 , respectively. As shown in Table 2, $\mathrm{H} / \mathrm{C}$ ratio of DEFB was slightly lower in comparison with EFB which decreased from 1.66 to 1.52. Similar trend was also observed for $\mathrm{H} / \mathrm{C}$ and $\mathrm{O} / \mathrm{C}$ ratio of TEFB and TDEFB when the torrefaction temperature was increased from 200 to $280{ }^{\circ} \mathrm{C}$. This clearly indicated that, moisture and light volatile compounds which contain high hydrogen and oxygen were eliminated from EFB and DEFB, and consequently the carbon content of the materials increased after torrefaction. In general, sulphur and nitrogen content in biomass sample is much lower than that of coal [35].

Both demineralization and torrefaction pre-treatments could remove sulphur $(\mathrm{S})$ and reduce the nitrogen $(\mathrm{N})$ content of EFB (Table 2). This result was supported by previous studies reporting that sulphur and nitrogen content in biomass were reduced after torrefaction [39] and wet torrefaction [37,39].

Table 2. Ultimate analysis, atomic ratio and calorific value of raw and pre-treated empty fruit bunch (EFB)

\begin{tabular}{llllll}
\hline Sample & \multicolumn{3}{c}{ Ultimate analysis } & \multicolumn{2}{c}{$\begin{array}{c}\text { Calorific value } \\
\left(\mathrm{MJ} \mathrm{kg}^{-1}\right)\end{array}$} \\
\cline { 2 - 4 } & $\mathrm{O} / \mathrm{C}$ & $\mathrm{H} / \mathrm{C}$ & $\mathrm{N} / \mathrm{C}$ & $\mathrm{S} / \mathrm{C}$ & 17.80 \\
\hline EFB & 0.79 & 1.66 & 0.03 & - & 17.30 \\
\hline TEFB 200 & 0.78 & 1.53 & 0.00 & - & 18.50 \\
TEFB 220 & 0.74 & 1.48 & 0.01 & 18.90 \\
TEFB 240 & 0.69 & 1.27 & 0.00 & 20.60 \\
TEFB 260 & 0.57 & 1.05 & 0.00 & 21.10 \\
TEFB 280 & 0.48 & 0.99 & 0.00 & 23.50 \\
\hline TDEFB 200 & 0.73 & 1.50 & 0.00 & - & 17.90 \\
TDEFB 220 & 0.70 & 1.43 & 0.00 & 18.20 \\
TDEFB 240 & 0.68 & 1.39 & 0.00 & 19.70 \\
TDEFB 260 & 0.63 & 1.27 & 0.00 & 21.10 \\
TDEFB 280 & 0.45 & 0.99 & 0.01 & 23.50
\end{tabular}

Figure 2 compares the FTIR spectra of EFB with TEFB and TDEFB at various torrefaction temperatures. The FTIR spectra showed four prominent absorption peaks at $3345 \mathrm{~cm}^{-1}$ (i), $2920 \mathrm{~cm}^{-}$ ${ }^{1}$ and $2850 \mathrm{~cm}^{-1}$ (ii), $1650 \mathrm{~cm}^{-1}$ and $1710 \mathrm{~cm}^{-1}$ (iii) and $1033 \mathrm{~cm}^{-1}$ (iv) which are assigned to the vibration of hydroxyl group $(-\mathrm{OH})$, aliphatic methylene group, carbonyl groups $(\mathrm{C}=\mathrm{O})$ from aldehydes 


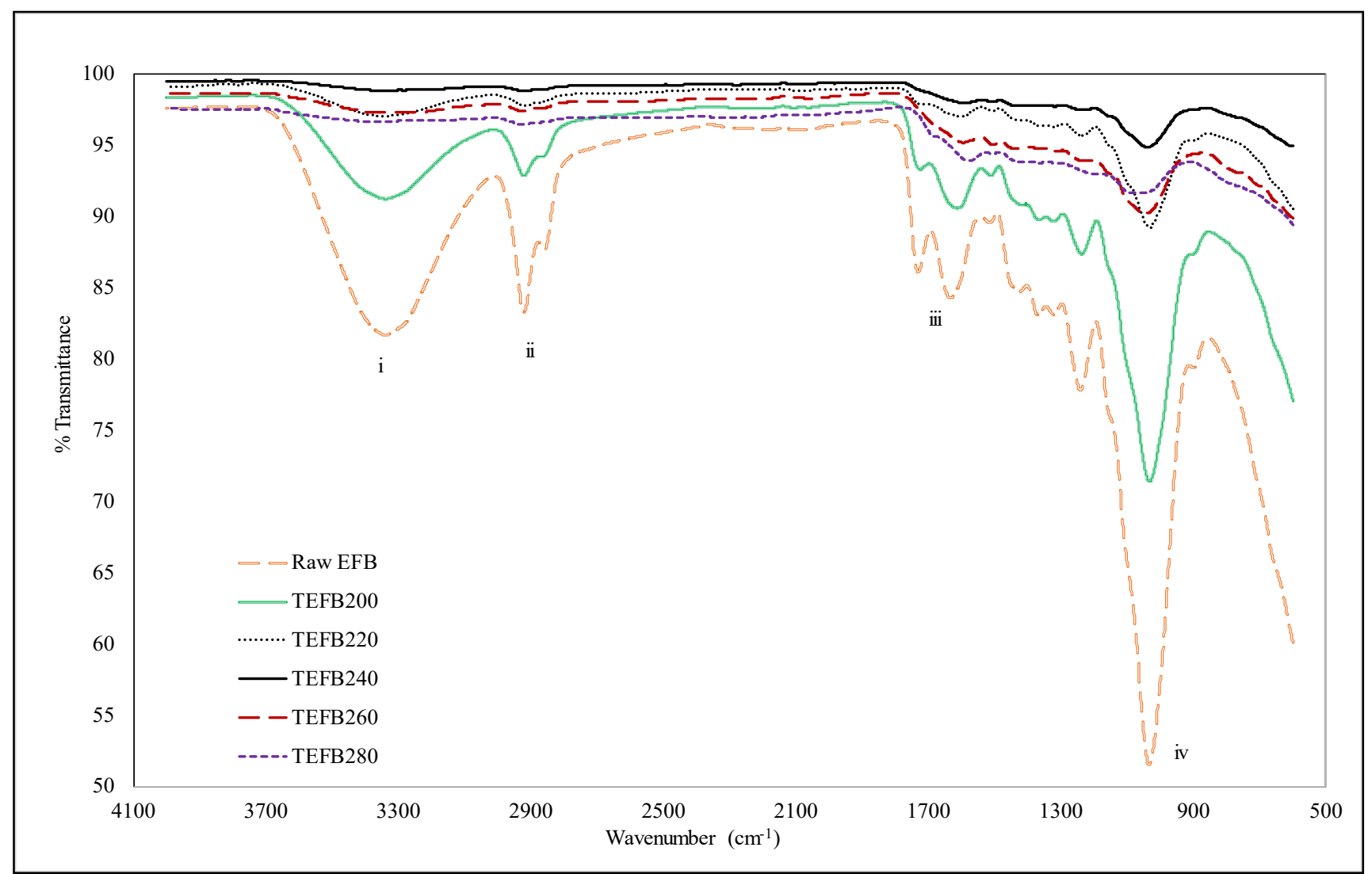

(a)

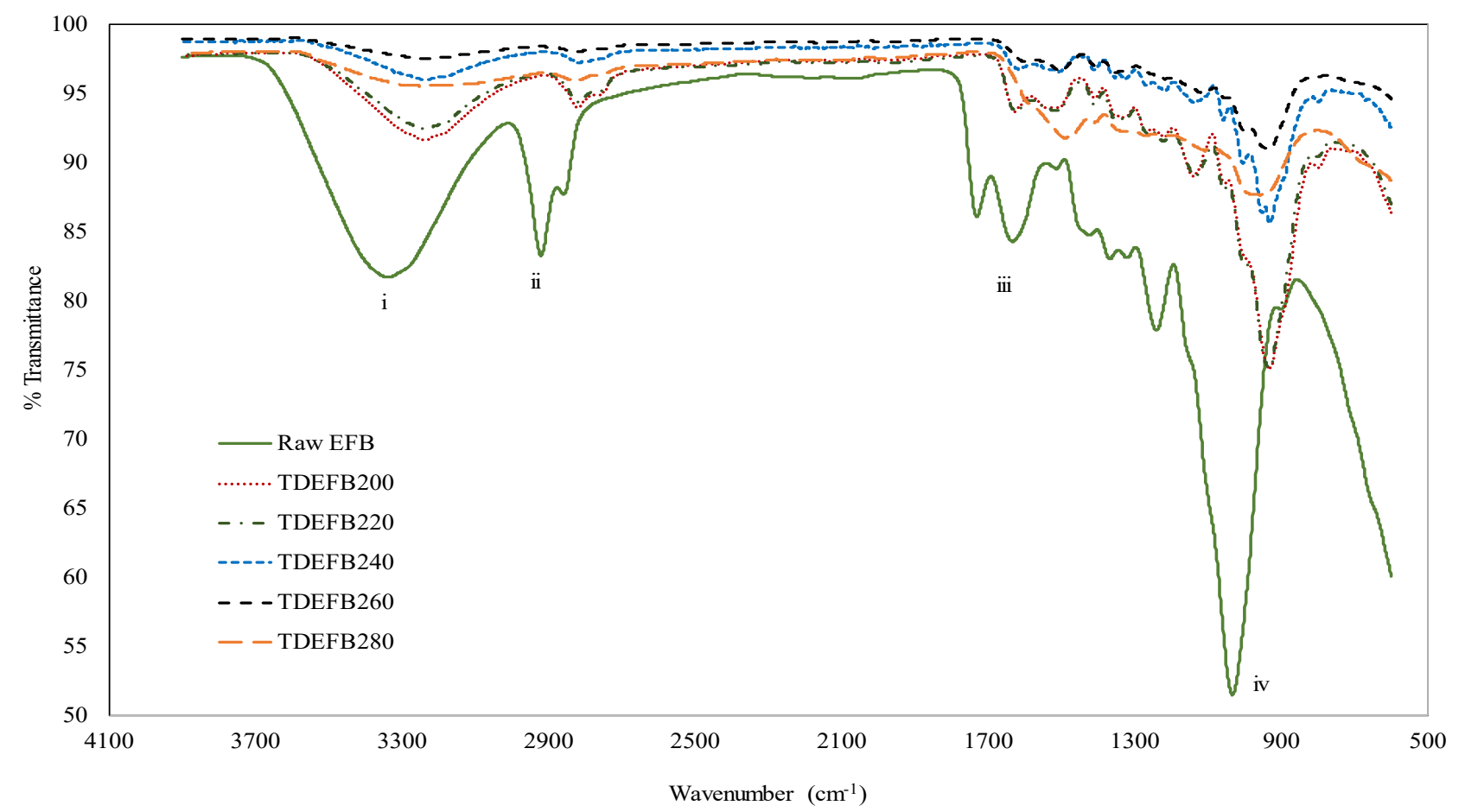

(b)

Figure 2. FTIR spectra of a) EFB and TEFB and, b) EFB and TDEFB at various torrefaction temperatures 
and acids, and ethers, phenol and alcohol $(\mathrm{C}-\mathrm{O}, \mathrm{C}=\mathrm{C}$ and $\mathrm{C}-\mathrm{C}-\mathrm{O}$ stretching), respectively. The spectra of EFB shows clearly a broad envelope of $3345 \mathrm{~cm}^{-1}$ which corresponds to the hydroxyl group. However, this peak was remarkably weakened as the torrefaction temperature was increased due to the removal of moisture through dehydration process.

The peaks at $2920 \mathrm{~cm}-1$ and $2850 \mathrm{~cm}-1$ corresponding to the hydrocarbons and carbonyl species, respectively show similar trend that represents the evolution of carbon dioxide and methane, and extent of the decomposition of hemicellulose for torrefied EFB. Apparently, the intensities of spectral peaks (iii) appearing at $1650 \mathrm{~cm}-1$ and $1710 \mathrm{~cm}-1$ which were assigned to alkene $(\mathrm{C}=\mathrm{C})$ and carbonyl $(\mathrm{C}=\mathrm{O})$, respectively decreased for both TEFB and TDEFB samples in comparison to EFB. This observation indicates that oxygen and hydrogen have been removed through decarboxylation and dehydration of hemicellulose during torrefaction and demineralisation of EFB. This is in agreement with similar findings reported by other researchers $[39,40]$.

Previous research [41] reported that torrefaction pre-treatment could reduce the acid content of bio oil due to the removal of acetyl group in hemicellulose which is the primary source of acetic acid. Torrefaction of EFB and DEFB samples above $240{ }^{\circ} \mathrm{C}$ decreased the intensity of the peak originating form acetyl group $(1710 \mathrm{~cm}-$ 1), which is observation attributed to deacetylation of hemicellulose. Therefore, torrefaction temperature of $240{ }^{\circ} \mathrm{C}$ were selected for TEFB and TDEFB in bio fuel feedstock. This is due to the fact that at this temperature, the percentages of torrefaction yield of TEFB240 and TDEFB240 were found higher than that of EFB and DEFB samples at the torrefaction temperatures of 260 and $280{ }^{\circ} \mathrm{C}$ with less acetyl group content

The Van Krevelen diagram can be used to analyse the characteristics of torrefied biomass based on the relative increase in carbon content while decreasing the relative amounts of hydrogen and oxygen [35].

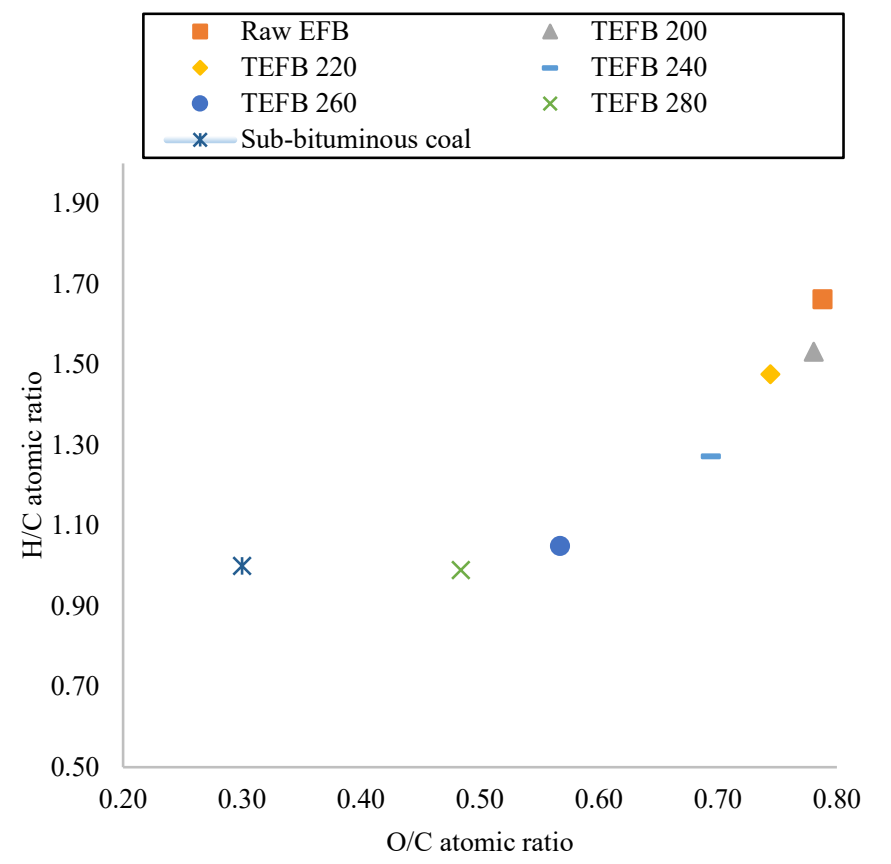

(a)
With reference to Figure $3 \mathrm{a}$, the Van Krevelen diagram of TEFB and EFB shows the reduction in elementary composition of oxygen and hydrogen with the increase of torrefaction temperature. Comparable tendency was also observed for TDEFB as shown in Figure 3b. The changes in elementary composition of both torrefied samples resemble sub-bituminous coal referring to the Van Krevelen plot. These results indicate that some alterations in fuel properties [28] that enhance the quality of torrefied EFB as a solid fuel feedstock [34].

\subsection{The effect of sequential pre-treatment on fuel properties of $E F B, T E F B$ and TDEFB}

The mass and energy yields and energy density were calculated using equations 1, 2 and 3, respectively and the data are illustrated in Figure 4. Indeed, it is seen from Figure 4 that torrefaction pretreatment had an important impact on the mass and energy yields and energy density. With the increase in torrefaction temperature from 200 to $280{ }^{\circ} \mathrm{C}$, the mass and energy yields for TDEFB declined gradually from 77.88 to $34.96 \%$ and 80.94 to $46.15 \%$, respectively. The same tendency of reduction was also observed for the mass and energy yields of the TDEFB sample in the range from 86.01 to $45.89 \%$ and from $86.49 \%$ to $60.59 \%$, respectively.

However, mass and energy yields of TDEFB were slightly higher than that of TEFB. These results may be associated with the trending of volatile matter of proximate analysis as shown in Table 1 in previous section. TEFB suffered from obvious decreases of mass and energy yields specifically at the temperatures above 240 ${ }^{\circ} \mathrm{C}$. Meanwhile, TDEFB was able to retain a drastic loss of mass and energy yields prior to the pre-treatment. In addition, the energy density of TEFB and TDEFB increased in the range from 1.01 to 1.34 with the increased of the torrefaction temperature from 200 to $280^{\circ} \mathrm{C}$. This was due to the major decomposition of hemicellulose and partial decomposition of cellulose during torrefaction resulting in an increase in calorific value, and is similar to the results reported by other researchers $[41,39,32]$.

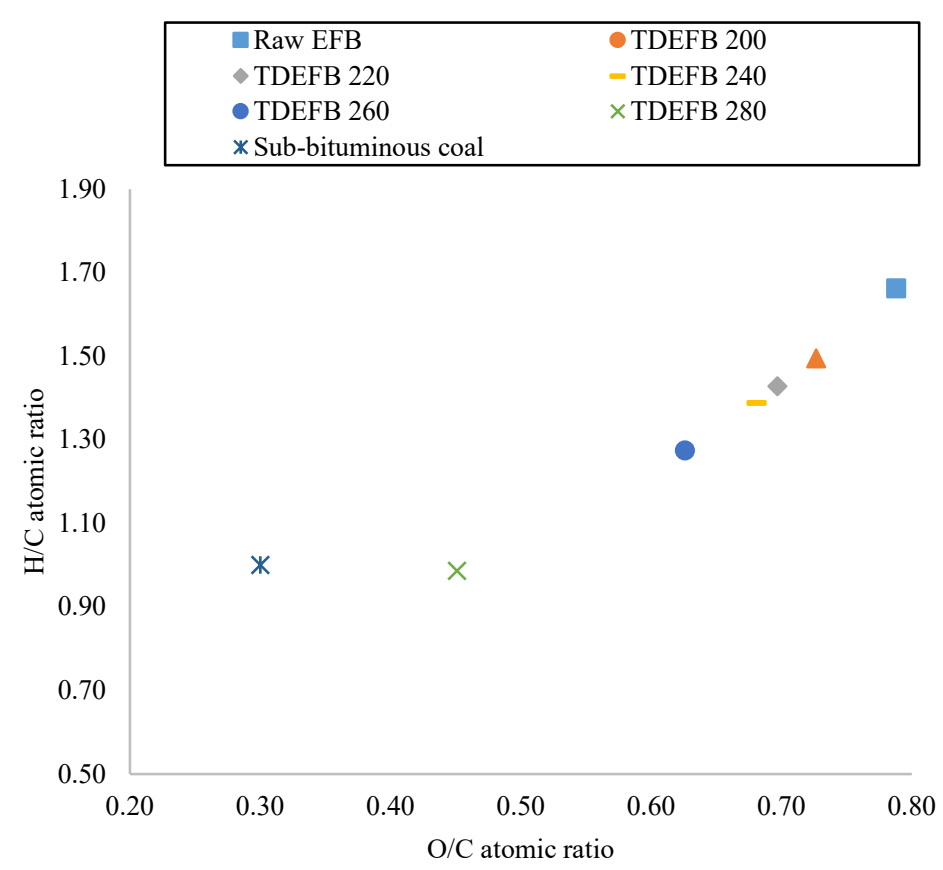

(b)

Figure 3. Van Krevelen diagram for chemical composition of a) EFB and TEFB at various torrefaction temperatures and b) EFB and TDEFB at various torrefaction temperatures (sub-bituminous coal as reference) 


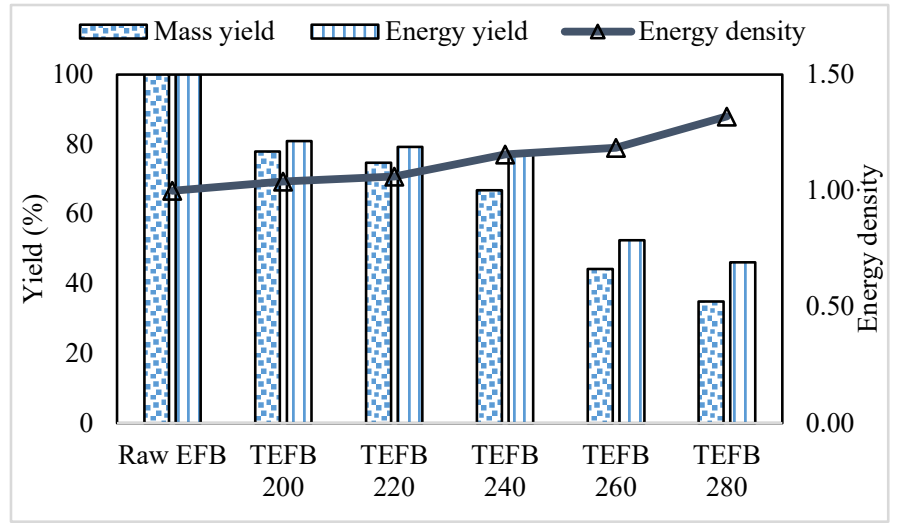

(a)

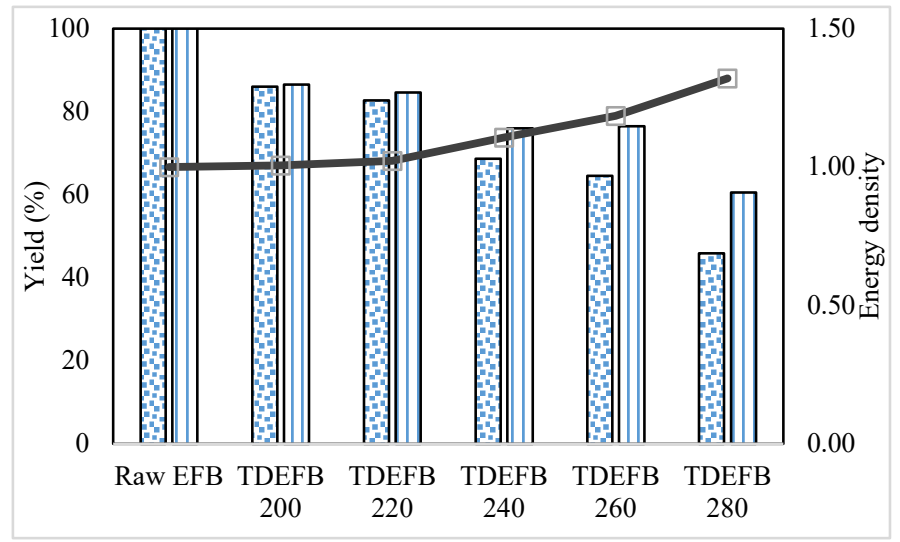

(b)

Figure 4. Mass and energy yield and calorific value a) TEFB and b) TDEFB

According to our previous work, pre-treated palm wastes such as EFB and palm kernel shell (PKS) using physical and chemical pretreatments were identified the appropriate solid biofuel for further thermal conversions such as combustion, pyrolysis, gasification and other applications. Further, it also promote to the enrichment of energy security, decrease in $\mathrm{CO} 2$ emissions, sustenance to the development of renewable energy and high advantageous to the agricultural and forestry activity $[44,45]$.

\subsection{Thermogravimetric analysis}

Based on the results obtained from proximate and ultimate analyses, fuel properties and FTIR data of EFB, TEFB and TDEFB, both TEFB 240 and TDEFB 240 were obtained following the pyrolysis process. Thermogravimetric analyser (TGA) was used to observe the thermal behaviour and to obtain the kinetic parameters of all samples. The weight loss (TG) and the differential weight loss (DTG) curves of EFB, TEFB 240 and TDEFB 240 are illustrated in Figure 5 and 6, respectively.

From Figure 5, the first weight loss is identified at approximately $128^{\circ} \mathrm{C}$ for all samples. This corresponds to the removal of water molecules which are adsorbed on the surface of EFB and is shown by the first small peak in Figure 6 . The second peak shows that the major weight loss occurs from 200 to $350{ }^{\circ} \mathrm{C}$ for EFB and from 290 to $350^{\circ} \mathrm{C}$ for TEFB 240 and TDEFB 240. This could be due to the active pyrolysis of hemicellulose and cellulose portion in EFB. The cellulose and hemicelluloses contents of EFB are higher than those of TEFB 240 and TDEFB 240. Therefore, the active pyrolysis process began at a much lower temperature for EFB compared to TEFB 240 and TDEFB 240. This devolatilization stage of EFB resulted in changes via occurrence of simultaneous reactions such as depolymerization, decarboxylation, dehydration and decarbonylation [6, 42].

The TEFB 240 sample had undergone single pre-treatment of torrefaction at $240{ }^{\circ} \mathrm{C}$ whereas the TDEFB 240 sample had experienced sequential demineralization and torrefaction at $240{ }^{\circ} \mathrm{C}$ during pre-treatment stage which resulted in the cleavage of $\mathrm{C}-\mathrm{O}$ bonds in hemicelluloses and decrease in cellulosic content of EFB. Therefore, the active pyrolysis processes of TEFB 240 and TDEFB 240 are contributed by the remaining lignocellulosic content of EFB that shifts the process to a maximum region. It can be seen from Figure 6 that, the peak temperature shifts from 318 to $336^{\circ} \mathrm{C}$ first and finally to $354^{\circ} \mathrm{C}$ for EFB, TEFB 240 and TDEFB 240, respectively. This trend is similar to previous study [20], where the main weight loss was observed in the range from 250 to $450{ }^{\circ} \mathrm{C}$ with the corresponding DTG curve appearing from 350 to $390{ }^{\circ} \mathrm{C}$ and this showed the decomposition temperature regions represented by hemicellulose, cellulose and lignin.

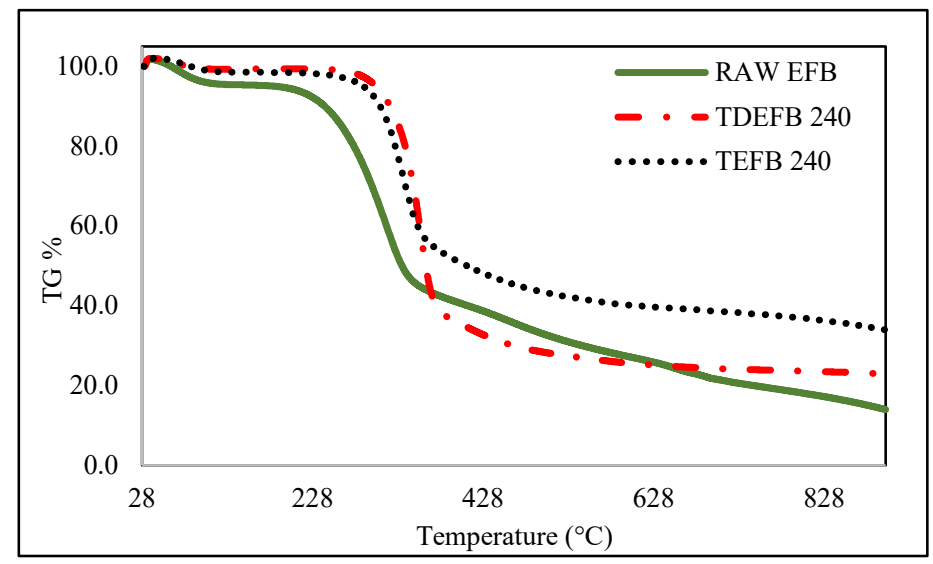

Figure 5. The weight loss (TG) of EFB, TEFB and TDEFB at heating rate of 20 ${ }^{\circ} \mathrm{C}$ min-1 under inert condition

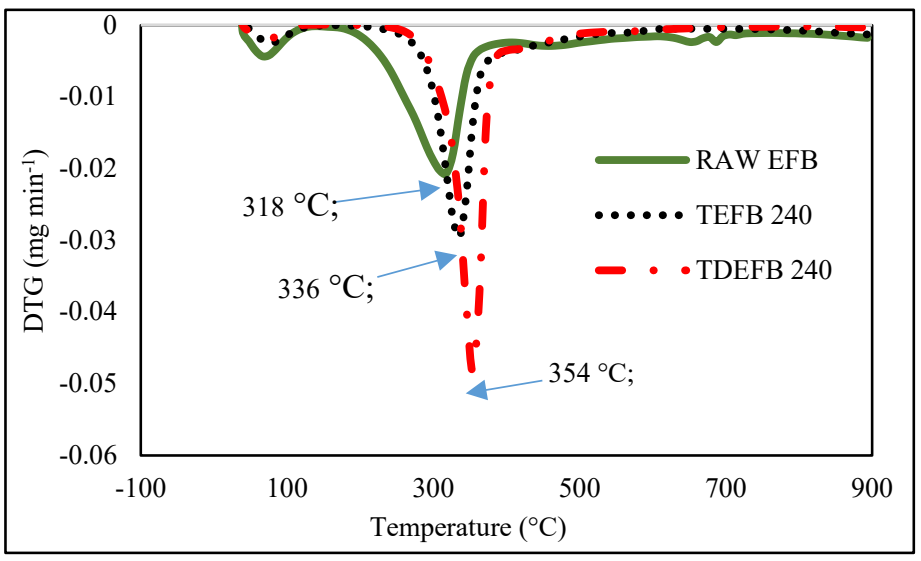

Figure 6 . The weight loss rate (DTG) of EFB, TEFB and TDEFB at a heating rate of $20{ }^{\circ} \mathrm{C} \mathrm{min}-1$ under inert condition

The third stage is observed at a temperature range from 350 to $600{ }^{\circ} \mathrm{C}$ in Figure 5. This is a slow weight loss taking place over a wide range of temperature and is due to the composition of lignin in the samples. In summary, three temperature regions are clearly seen for decomposition of lignocellulosic of raw EFB, TEFB 240 and TDEFB 240 
N.N. Kasim et al. / Advances in Science, Technology and Engineering Systems Journal Vol. 3, No. 5, 365-373 (2018)

Table 3. The kinetic parameters for raw EFB, TEFB 240 and TDEFB 240 pyrolysis obtained by Coats-Redfern model

\begin{tabular}{llccc}
\hline Samples & Equation & $\begin{array}{c}\text { Activation energy, } \mathrm{E}_{\mathrm{a}} \\
\left(\mathrm{kJ} \mathrm{mol}^{-1}\right)\end{array}$ & $\mathrm{R}^{2}$ & $\begin{array}{c}\text { Pre-exponential } \\
\text { factor, } \ln \mathrm{A}\left(\mathrm{min}^{-1}\right)\end{array}$ \\
\hline EFB & $\mathrm{y}=-8588 \mathrm{x}+1.8068$ & 71.40 & 0.9956 & 10.87 \\
TEFB 240 & $\mathrm{y}=-14573 \mathrm{x}+10.81$ & 121.16 & 0.9898 & 20.40 \\
TDEFB 240 & $\mathrm{y}=-16592 \mathrm{x}+13.419$ & 137.42 & 0.9888 & 23.13 \\
\hline
\end{tabular}

\subsection{Thermal degradation kinetic analysis}

The thermogravimetric data obtained at a heating rate of $20^{\circ} \mathrm{C}$ $\min ^{-1}$ were used to calculate the kinetics parameters such as activation energy and pre-exponential factor, $\ln \mathrm{A}$ for EFB, TEFB 240 and TDEFB 240 using the Coats-Redfern method of the data obtained in the temperature range from 200 to $400{ }^{\circ} \mathrm{C}$. The plot of $\ln \left(-\ln (1-\alpha) / T^{2}\right)$ vs. $1 / T$ is illustrated in Figure. 7. The corresponding values of activation energy $\left(E_{a}\right)$, correlation coefficient $\left(\mathrm{R}^{2}\right)$ and intercepts are presented in Table 3.

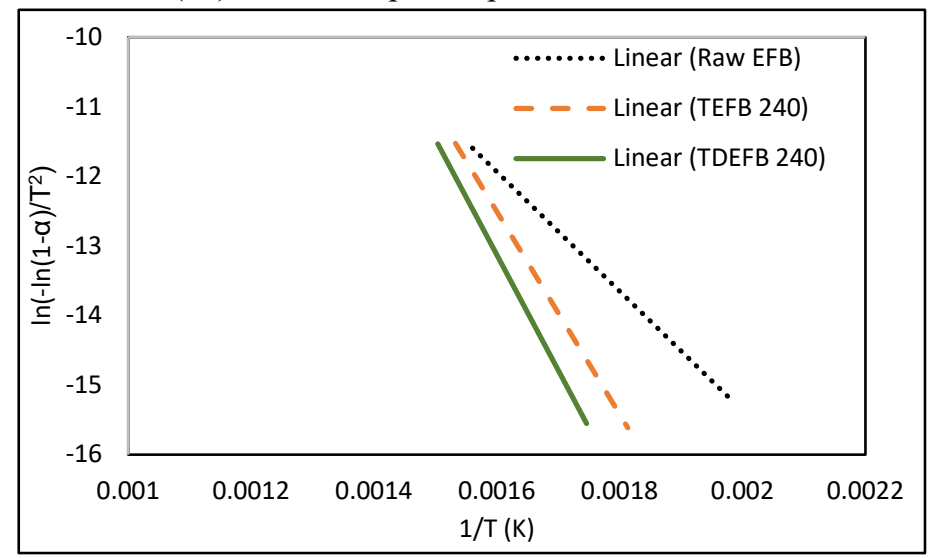

Figure 7. The plot of regression line was produced from value of $\ln [-\ln (1-\alpha) / \mathrm{T} 2$ against 1/T for EFB, TEFB 240 and TDEFB 240

The values of $R^{2}$ are above 0.96 indicating the present of a strong correlation between dependable and undependable parameters. From Table 3, the activation energy values for pyrolysis of TDEFB 240 and TEFB 240 were determined as 137.42 and $121.16 \mathrm{~kJ} \mathrm{~mol}^{-1}$, respectively. These values are higher than that for pyrolysis of EFB which is $71.40 \mathrm{~kJ} \mathrm{~mol}^{-1}$. The low activation energy of EFB pyrolysis is attributed to the devolatilization of hemicellulosic component [47].

The higher values of activation energy for pyrolysis of torrefied samples may be explained by the fact that pyrolysis of torrefied samples containing mainly C-C networks occurs at higher temperature which can be accompanied by a higher activation energy [20]. During torrefaction of TEFB 240 and TDEFB 240, the hemicellulosic component decomposes and results in the cleavage of $\mathrm{C}-\mathrm{O}$ and $\mathrm{C}-\mathrm{H}$ bonds. The removal of oxygen atoms occurs also during this stage either in the form of water or carbon monoxide.

\section{Conclusion}

In this work, the effects of sequential pre-treatment consist of demineralization and torrefaction on oil palm empty fruit bunch have been studied. This pre-treatment effectively enhances the quality of bio fuel feedstock by increasing the carbon content, eliminating the AAEMs content and reducing oxygen content. It was found that, this sequential pre-treatment improves the energy www.astesj.com density of the selected torrefied samples by decreasing oxygen content which contributed in increasing the calorific value. This results also can also be supported by decreasing the intensity of hydroxy and carbonyl peaks that was observed in FTIR spectra of the samples. According to thermogravimetric analysis, both samples showed the increasing in C-C networks that represent the removal of hemicellulose and rich in cellulose content. These results can be supported by increasing the activation energy of TEFB 240 and TDEFB 240 using Coats-Redfern method of kinetic study. Thus, this sequential pre-treatment is suggested to be the most effective approach for upgrading the quality of solid fuel feedstock for further thermal conversion process for the future.

\section{Acknowledgment}

The authors acknowledge Universiti Teknologi MARA and Universiti Malaysia Perlis (UniMAP) for providing laboratory and instrumentation facilities during the research work. The authors would like to thank also to United Oil Palm Industries Sdn Bhd located in Nibong Tebal, Pulau Pinang, Malaysia for supplying the oil palm EFB sample.

\section{Conflict of Interest}

The authors declare no conflict of interest.

\section{References}

[1] N. N. Kasim, K. Ismail, M. A. M. Ishak, R. Ahmad, A. R. Mohamed, and W. I. Nawawi, "Demineralization of oil palm empty fruit bunch (EFB) intended as a high quality bio-oil feedstock," 4th IET Clean Energy Technol. Conf. (CEAT 2016), 107 (6.), 2016. https://doi:10.1049/cp.2016.1364.

[2] B. R. Singh and O. Singh, "Global Trends of Fossil Fuel Reserves and Climate Change in the 21st Century," Foss. Fuel Environ., 167-192, 2012. https://doi:10.5772/38655.

[3] M. V. Kok and E. Özgür, "Thermal analysis and kinetics of biomass samples," $\begin{array}{llll}\text { Fuel Process. } & \text { Technol.,106, }\end{array}$ https://doi:10.1016/j.fuproc.2012.10.010.

[4] N. Abdullah and F. Sulaiman, "The oil palm wastes in Malaysia," in Biomass Now - Sustainable Growth and Use, 75-100, 2013. https://doi:10.5772/55302.

[5] A. R. Mohamed and Z. Hamzah, "An alternative approach for the screening of catalytic empty fruit bunch (EFB) pyrolysis using the values of activation energy from a thermogravimetric study," React. Kinet. Mech. Catal.,114, 529-545, 2014. https://doi:10.1007/s11144-014-0798-8.

[6] X. Y. Lim and J. M. Andrésen, "Pyro-catalytic deoxgenated bio-oil from palm oil empty fruit bunch and fronds with boric oxide in a fixed-bed reactor," Fuel Process. Technol., 92(9), 1796-1804, 2011. https://doi:10.1016/j.fuproc.2011.04.033.

[7] M. a. Aziz, K. M. Sabil, Y. Uemura, and L. Ismail, "A study on torrefaction of oil palm biomass,” Journal of Applied Sciences, 12(11). 1130-1135, 2012. https://doi:10.3923/jas.2012.1130.1135.

[8] J. Mabrouki, M. A. Abbassi, K. Guedri, A. Omri, and M. Jeguirim, "Simulation of biofuel production via fast pyrolysis of palm oil residues," Fuel,159,819-827, 2015. https://doi:10.1016/j.fuel.2015.07.043.

[9] Y. Uemura, W. N. Omar, T. Tsutsui, and S. B. Yusup, "Torrefaction of oil palm wastes," Fuel, 90(8), 2585-2591, 2011. https://doi:10.1016/j.fuel.2011.03.021.

[10] S. Matali, N. A. Rahman, S. S. Idris, N. Yaacob, and A. B. Alias, "Lignocellulosic Biomass Solid Fuel Properties Enhancement via Torrefaction," Procedia Eng., 148, 671-678, 2016. 
https://doi:10.1016/j.proeng.2016.06.550.

[11] T. Wigley, A. C. K. Yip, and S. Pang, "The use of demineralisation and torrefaction to improve the properties of biomass intended as a feedstock for fast pyrolysis," J. Anal. Appl. Pyrolysis, 113, 296-306, 2015. https://doi:10.1016/j.jaap.2015.02.007.

[12] T. Wigley, A. C. K. Yip, and S. Pang, "Pretreating biomass via demineralisation and torrefaction to improve the quality of crude pyrolysis oil," Energy, 109, 481-494, 2016. https://doi:10.1016/j.energy.2016.04.096.

[13] N. Abdullah, F. Sulaiman, and H. Gerhauser, "Characterisation of oil palm empty fruit bunches for fuel application,” J. Phys. Sci., 22(1), 1-24, 2011.

[14] K. Kaminaka, Y. Matsumura, W. Noaman Omar, and Y. Uemura, "Process evaluation for torrefaction of empty fruit bunch in malaysia," J. Japan Pet. Inst., 57(2), 88-93, 2014.

[15] Y. Uemura, W. Omar, N. A. Othman, S. Yusup, and T. Tsutsui, "Torrefaction of oil palm EFB in the presence of oxygen," Fuel, 103, 156160, 2013. https://doi:10.1016/j.fuel.2011.11.018.

[16] A. Shariff, N. S. M. Aziz, and N. Abdullah, "Slow Pyrolysis of Oil Palm Empty Fruit Bunches for Biochar Production and Characterisation," J. Phys. Sci., 25(2), 97-112, 2014.

[17] S. Zhang, Q. Dong, L. Zhang, Y. Xiong, X. Liu, and S. Zhu, "Effects of water washing and torrefaction pretreatments on rice husk pyrolysis by microwave heating." " Bioresour. Technol., 193, 442-448, 2015. https://doi:10.1016/j.biortech.2015.06.142.

[18] J. M. Reckamp, R. A. Garrido, and J. A. Satrio, "Selective pyrolysis of paper mill sludge by using pretreatment processes to enhance the quality of bio-oil and biochar products," Biomass and Bioenergy, 71, 235-244, 2014. https://doi:10.1016/j.biombioe.2014.10.003

[19] D. Chen, J. Mei, H. Li, Y. Li, M. Lu, T. Ma, and Z. Ma, "Combined pretreatment with torrefaction and washing using torrefaction liquid products to yield upgraded biomass and pyrolysis products," Bioresour. Technol., 228, 62-68, 2017. https://doi:10.1016/j.biortech.2016.12.088.

[20] L. Cao, X. Yuan, L. Jiang, C. Li, Z. Xiao, Z. Huang, X. Chen, G. Zeng, and $\mathrm{H}$. Li, "Thermogravimetric characteristics and kinetics analysis of oil cake and torrefied biomass blends," Fuel, 175, 129-136, 2016. https://doi:10.1016/j.fuel.2016.01.089.

[21] M. Kopczyński, A. Plis, and J. Zuwała, "Thermogravimetric and kinetic analysis of raw and torrefied biomass combustion," Chem. Process Eng. Inz. Chem. i Proces., 36(2), 209-223, 2015. https://doi:10.1515/cpe-20150014.

[22] P. Ninduangdee, V. I. Kuprianov, E. Y. Cha, R. Kaewrath, P. Youngyuen, and W. Atthawethworawuth, Thermogravimetric Studies of Oil Palm Empty Fruit Bunch and Palm Kernel Shell: TG/DTG Analysis and Modeling, 79, 2015. https://doi:10.1016/j.egypro.2015.11.518.

[23] G. Wang, J. Zhang, J. Shao, Z. Liu, G. Zhang, T. Xu, J. Guo, H. Wang, R. $\mathrm{Xu}$, and $\mathrm{H}$. Lin, "Thermal behavior and kinetic analysis of co-combustion of waste biomass/low rank coal blends," Energy Convers. Manag., 124, 414426, 2016. https://doi:10.1016/j.enconman.2016.07.045.

[24] S. D. Stefanidis, E. Heracleous, D. T. Patiaka, K. G. Kalogiannis, C. M. Michailof, and A. A. Lappas, "Optimization of bio-oil yields by demineralization of low quality biomass," Biomass and Bioenergy, 83, 105115, 2015. https://doi:10.1016/j.biombioe.2015.09.004.

[25] P. Basu and P. Basu, "Chapter 13 - Analytical Techniques," in Biomass Gasification, Pyrolysis and Torrefaction, 439-455, 2013. https://doi:10.1016/B978-0-12-396488-5.00013-7.

[26] S. S. Idris, N. A. Rahman, K. Ismail, A. B. Alias, Z. A. Rashid, and M. J. Aris, "Investigation on thermochemical behaviour of low rank Malaysian coal, oil palm biomass and their blends during pyrolysis via thermogravimetric analysis (TGA)," Bioresour. Technol., 101(12), 4584 4592, 2010. https://doi:10.1016/j.biortech.2010.01.059.

[27] K. Singh and J. Zondlo, "Characterization of fuel properties for coal and torrefied biomass mixtures," J. Energy Inst., 2016. https://doi:10.1016/j.joei.2016.05.012.

[28] T. G. Bridgeman, J. M. Jones, A. Williams, and D. J. Waldron, "An investigation of the grindability of two torrefied energy crops," Fuel, 89,(12), 3911-3918, 2010. https://doi:10.1016/j.fuel.2010.06.043.

[29] B. Bevan, A. Ahmad, A. Johari, T. Amran, and T. Abdullah, "Torrefaction of Pelletized Oil Palm Empty Fruit Bunches," in The 21st International Symposium on Alcohol Fuels - 21st ISAF, 15-19, 2015.

[30] M. A. Islam, M. Asif, and B. H. Hameed, "Pyrolysis kinetics of raw and hydrothermally carbonized Kar (Pongamia pinnata) fruit hulls via thermogravimetric analysis," Bioresour. Technol., 179, 227-233, 2015. https://doi:10.1016/j.biortech.2014.11.115.

[31] A. R. Mohamed, Z. Hamzah, M. Z. M. Daud, and Z. Zakaria, "The Effects of Holding Time and the Sweeping Nitrogen Gas Flowrates on the Pyrolysis of EFB using a Fixed-Bed Reactor," Procedia Eng., 53, 185-191, 2013. https://doi:10.1016/j.proeng.2013.02.024.

[32] S. Ren, H. Lei, L. Wang, Q. Bu, S. Chen, and J. Wu, "Thermal behaviour and kinetic study for woody biomass torrefaction and torrefied biomass pyrolysis by TGA," Biosyst. Eng., 116(4), 420-426, 2013. https://doi:10.1016/j.biosystemseng.2013.10.003.

[33] J. Meng, J. Park, D. Tilotta, and S. Park, "The effect of torrefaction on the chemistry of fast-pyrolysis bio-oil.," Bioresour. Technol., 111, 439-446, 2012. https://doi:10.1016/j.biortech.2012.01.159.

[34] Y. Yue, H. Singh, B. Singh, and S. Mani, "Torrefaction of Sorghum Biomass to Improve Fuel Properties," Bioresour. Technol., 232, 372-379, 2017. https://doi:10.1016/j.biortech.2017.02.060.

[35] W.-H. Chen, J. Peng, and X. T. Bi, "A state-of-the-art review of biomass torrefaction, densification and applications," Renew. Sustain. Energy Rev., 44, 847-866, 2015. https://doi:10.1016/j.rser.2014.12.039.

[36] A. Saddawi, J. M. Jones, and A. Williams, "Influence of alkali metals on the kinetics of the thermal decomposition of biomass," Fuel Process. Technol., 104, 189-197, 2012. https://doi:10.1016/j.fuproc.2012.05.014.

[37] P. Basu, Torrefaction. Elsevier Inc., 2013. https://doi:10.1016/B978-0-12396488-5.00004-6.

[38] S. Zhang, T. Chen, W. Li, Q. Dong, and Y. Xiong, "Bioresource Technology Physicochemical properties and combustion behavior of duckweed during wet torrefaction", 218, 1157-1162, 2016.http:// 10.1016/j.enconman.2016.07.045

[39] W.-H. Chen, S.-W. Du, C.-H. Tsai, and Z.-Y. Wang, "Torrefied biomasses in a drop tube furnace to evaluate their utility in blast furnaces," Bioresour. Technol., 111, 433-438, 2012. https://doi:10.1016/j.biortech.2012.01.163.

[40] A. Zheng, Z. Zhao, Z. Huang, K. Zhao, G. Wei, X. Wang, F. He, and H. Li, "Catalytic fast pyrolysis of biomass pretreated by torrefaction with varying severity," Energy \& Fuels, 28, 5804-5811, 2014. https://doi:10.1021/ef500892k.

[41] S. Wang, G. Dai, B. Ru, Y. Zhao, X. Wang, J. Zhou, Z. Luo, and K. Cen, "Effects of torrefaction on hemicellulose structural characteristics and pyrolysis behaviors," Bioresour. Technol., 218, 1106-1114, 2016. https://doi:10.1016/j.biortech.2017.02.120.

[42] Y. Joshi, M. Di Marcello, and W. de Jong, "Torrefaction: Mechanistic study of constituent transformations in herbaceous biomass," J. Anal. Appl. Pyrolysis, 115, 353-361, 2015. https://doi:10.1016/j.biortech.2016.07.075.

[43] D. Chen, K. Cen, X. Jing, J. Gao, C. Li, and Z. Ma, "An approach for upgrading biomass and pyrolysis product quality using a combination of aqueous phase bio-oil washing and torrefaction pretreatment," Bioresour. Technol., 233, 150-158, 2017.

[44] N. N. Kasim, K. Ismail, M. A. M. Ishak, R. Ahmad, A. R. Mohamed, and W. I. Nawawi, "Palm deto : resourceful , sustainable and favorable solid biofuel," 2, 391-397, 2017.

[45] R. Ahmad, M. A. M. Ishak, K. Ismail, and N. N. Kasim, "Co- palm: versatile, clean and enriched energy fuel," 2, 327-331, 2017.

[46] S. S. Mohtar, T. N. Z. Tengku Malim Busu, A. M. Md Noor, N. Shaari, and H. Mat, "An ionic liquid treatment and fractionation of cellulose, hemicellulose and lignin from oil palm empty fruit bunch," Carbohydr. Polym., 166, 291-299, 2017. https://doi:10.1016/j.carbpol.2017.02.102.

[47] H. Yang, R. Yan, H. Chen, D. H. Lee, and C. Zheng, "Characteristics of hemicellulose, cellulose and lignin pyrolysis," Fuel,86(12-13), 1781-1788, 2007. https://doi:10.1016/j.fuel.2006.12.013. 